\title{
Cost of neuroimaging of patients with vertigo in emergency department
}

\section{Acil servise baş dönmesi şikayeti ile başvuran hastalarda nörogörüntüleme maliyeti}

\author{
(ㄱ) Ali Kablan, ${ }^{1}$ (b) Serhat Karaman, ${ }^{2}$ 마 Nurşah Başol ${ }^{2}$ \\ 'Department of Emergency Medicine, Mardin State Hospital, Mardin, Turkey \\ ${ }^{2}$ Department of Emergency Medicine, Gaziosmanpasa University Faculty of Medicine, Tokat, Turkey
}

\begin{abstract}
Introduction: The fact that many diseases cause symptoms of vertigo and that some of them are life-threatening make it difficult to manage vertigo in emergency departments (ED). Parallel to these difficulties, the number of neuroimaging use in diagnosis is increasing. In this study, it is aimed to evaluate the neuroimaging costs of patients with vertigo in ED.

Methods: The study was carried out with a retrospective review of the files of the patients with vertigo who were admitted to ED between 01.01.2013 and 31.12.2013. Patients were classified into 6 groups; central, peripheral, cardiac and blood pressure-induced, induced by internal causes, psychogenic, and vertigo related to other causes. Costs and the total cost of these groups were determined and the ratios were analyzed statistically.

Results: Of the 381 patients; 31 (8.1\%) patients were seen to be in the central, 175 (45.9\%) in the peripheral vertigo. 72 of patients were seen to have been examined with computerized tomography (CT) and 35 with magnetic resonance imaging (MRI). Neuroimaging was observed to have been implemented mostly on the central induced group. The highest neuroimaging cost was in the peripheral vertigo group. However, when the cost per patient was calculated, the group with the lowest cost of each patient was the peripheral vertigo group.
\end{abstract}

Discussion and Conclusion: This study is the first study in Turkey for the cost analysis patients with a complaint of vertigo in ED. Avoiding unnecessary costs, along with the algorithms to be developed, can be possible with good and accurate patient management in ED.

Keywords: Cost; emergency department; dizziness; neuroimaging; Vertigo.

\begin{abstract}
Özet
Amaç: Pek çok hastalığın baş dönmesi belirtisi vermesi ve bunlardan bazılarının hayatı tehdit edici nitelikte oluşu acil servislerde baş dönmesi yönetimini zorlaştırmaktadır. Bu zorluklara paralel olarak da tanıda nörogörüntüleme kullanım sayısı giderek artmaktadır. Bu çalışmada baş dönmesi şikayeti ile acil servise başvuran hastaların nörogörüntüleme maliyetleri açısından değerlendirilmesi amaçlanmıştır.

Gereç ve Yöntem: Çalışma hastanemiz Acil Tıp Kliniğine 01.01.2013-31.12.2013 tarihleri arasında ana şikayeti baş dönmesi olan hastaların dosyalarının geriye dönük incelenmesi ile yürütüldü. Tüm hastaların dosya bilgilerinden yaş, cinsiyet, anamnez, tanısal tetkikler ve yapılan tetkiklerin maliyeti veri toplama formlarına kaydedildi. Hastaların acil servis sonuç tanıları santral nedenli baş dönmesi, periferik nedenli baş dönmesi, kardiak ve tansiyon nedenli baş dönmesi, dahili nedenlere bağlı baş dönmesi, psikojenik nedenli baş dönmesi ve diğer nedenler olmak üzere 6 grupta sınıflandıııldı. Bu grupların maliyetleri ve toplam maliyet tespit edilerek oranları istatistiksel olarak incelendi.

Bulgular: Çalışmaya alınan 381 hastanın \%59.8'i kadın (n:228), \%40.2'si erkek (n:153) olup yaş ortalamaları 46,12 $\pm 18,92$ idi. Tanılarına göre gruplandııldığında santral nedenli baş dönmesi grubunda 31 (\%8.1), periferik grupta 175 (\%45.9), kardiyak veya tansiyon nedenli grupta 43 (\%11.2), dahili nedenli grupta 18 (\%4.7), psikojenik grupta $6(\% 1.5)$ ve diğer nedenli grupta 108 (\%28.3) hasta yer aldı. Tüm hastaların 72'sine (\%18.8) BT, 35'ine (\%9.1) MRG çekildiği gözlendi. En fazla santral nedenli gruba nörogörüntüleme yapıldığı görüldü(BT \%41.9, MRG \%32.2). Nörogörüntüleme maliyetinin en yüksek olduğu grup, periferik vertigo grubunda idi. Ancak hasta başı maliyet hesap edildiğinde, bir hastanın maliyetinin en az olduğu grup periferik vertigo grubuydu.

Sonuç: Acil servise baş dönmesi şikayeti ile başvuran hastaların yıl geçtikçe artması ve hekimlerin önemli bir patolojiyi atlamak istememesi nedeniyle bu hastaların hastane maliyetinin giderek arttığı bilinmektedir. Bu çalışma Türkiye'de acil servisteki baş dönmesi başvurularında maliyet analizinin yapıldığı ilk çalışmadır. Gereksiz maliyeti önlemek; geliştirilecek olan algoritmalarla birlikte, acil serviste iyi ve doğru bir hasta yönetimi ile mümkün olabilir.

Anahtar Sözcükler: Maliyet; acil servis; baş dönmesi; vertigo; nörogörüntüleme.
\end{abstract}

Corresponding (illetişim): Nurşah Başol, Gaziosmanpaşa Üniversitesi Tıp Fakültesi, Acil Tıp Anabilim Dalı, Tokat, Turkey E-mail (E-posta): drnursahbs@hotmail.com 
V ertigo is one of the most common reasons of patient admissions in both emergency departments (ED) and neurology departments. Literature informs that all admissions have reached $2.4 \%$, while ED arrivals have reached $26 \% .^{[1]}$ Despite this high prevalence, assessing vertigo is a challenging task for physicians. The scanty description of symptoms by patients, and confusing the concepts of vertigo, dizziness, light headedness, balance disorder, anxiety and exhaustion make it more difficult to make a diagnosis. ${ }^{[2]}$ The most common reason for dizziness is vertigo (54\%). ${ }^{[3]}$ Vertigo is defined as the movement perception without any actual movement.

Vertigo is classified in two groups; those being central and peripheral. Peripheral vertigo is generally benign. Central vertigo is, while quite uncommon, life threatening. ${ }^{[4]}$ Thus, the distinction must definitely be made in the ED. The aetiology, most of the time, can only be determined through the medical record and physical examination. ${ }^{[5]}$ Cases of vertigo in the ERs have been determined as $44 \%$ peripheral vertigo, $16 \%$ psychiatric reasons, $11 \%$ central vertigo. Benign Paroxysmal Positional Vertigo (BPPV) (16\%), labyrinthyris (9\%), and Menier (5\%) are seen as causes for general peripheral vertigo. Other reasons include Cerebro Vascular Diseases (CVD) (6\%), cardiac arrhythmias (1,5\%) and brain tumours (<1\%). $13 \%$ of the patients describe vertigo induced by unknown reasons. Some studies have reported the rate of unexplained vertigo cases as $40-80 \%$. ${ }^{[6]}$

The fact that the vertigo complaint is also indicative of some serious illnesses (posterior circulatory stroke, transient ischemic attack, cardiac arrhythmia, etc.) and the physician's desire to make a correct diagnosis increase the cost. ${ }^{[7]}$ However, an increase in the proportion of central pathologies over the years has also increased the concern for central pathology in patients with vertigo. The use of Computerized Tomography $(\mathrm{CT})$ and Magnetic Resonance Imaging (MRI) has thus increased over time. However, the ineffective use of neuroimaging has been one of the main causes of cost escalation. In the United States (USA), about 2.3 million people are admitted to ED due to vertigo. About $\$ 1.6$ billion is spent in the health sector per year on vertigo. ${ }^{[7]}$

In this study, it was aimed to determine the symptomatological and etiologic subgroups of patients examined for vertigo in the Gaziosmanpaşa University, Department of Emergency Medicine and to compare these data with the literature in the light of medical records, physical examination findings and examinations performed, and especially the neuroimaging costs.

\section{Materials and Method}

The study was carried out with a retrospective review of the files of the patients who are admitted to the ED between 01.01.2013 and 31.12.2013 for mainly vertigo, with the approval dated 07.07.2015 given by Gaziosmanpaşa University Faculty of Medicine, Clinical Research Ethical Board (GOP 14KAEK-234). Patients with the diagnosis code (ICD) R42 and those diagnosed with vertigo on the Enlil-His data system of the hospital have been included in the study. Patients with missing information have been excluded from the study.

Age, gender, time of admission, medical records, background information, diagnostic tests (laboratory results, brain imaging) were collected from the files of patients in data collection forms. Patients were assessed for additional diseases (such as chronic internal diseases, neurological diseases, psychiatric disorders, meningitis, benign paroxysmal positional vertigo (BPPV), previous LVH, malignancy) that can pose a risk for vertigo and for cerebrovascular disease.

The numbers of consultation, numbers of hospitalization days, numbers of rest days, imaging examinations (MRI, CT), blood laboratory cost information of all patients and ED annual invoice costs were recorded. The MRI imaging results of patients had been obtained with the device with the system number 60001MRS01, of the brand General Electric (Tesla 1.5), while the CT images were obtained with the Siemens Somatom Spirit.

Patients' ED diagnoses were classified into six groups: central vertigo, peripheral vertigo, cardiac and blood pressureinduced vertigo, vertigo induced by internal causes, psychogenic vertigo, and other causes.

Imaging reports of patients who underwent neuroimaging were reviewed. Those with central pathology after the CT reports were classified as Chronic atrophic changes, acute ischemia, mass, chronic atrophic changes + acute ischemia and other pathologies. After reviewing the MRI reports, acute diffuse restriction was classified as chronic ischemic findings, mass, and other pathologies.

According to physical examination findings, patients with slow onset of vertigo, weeks to months of vertigo, patients with findings of vertical nystagmus and CNS, or patients with neuroimaging pathology were included in the central vertigo group. Patients who described a normal and sudden onset vertigo and of whom the neuroimaging results and CNS examination are normal, those who have a positive Dix-Hallpike Test, those who have vertigo triggered by head movements, or those of whom the eardrum examination were pathological were included in the peripheral group. Patients with dysrhythmia and / or blood pressure abnormalities and those who do not fit the central and peripheral groups were included in the cardiac and blood pressure-induced group. Patients with glucose metabolism impairment, thyroid dysfunction, electrolyte imbalance and anaemia were grouped as vertigo induced by internal-caused cases. Patients with anxiety, depression, mood disorders were grouped as psychogenic. Patients outside these groups were classified as cases of "other causes".

\section{Statistical Analysis}

The statistical analyses were conducted on the package program named IBM SPSS for Windows, Version 22.00. Frequency and percentage values were used in summarizing categorical variables, while arithmetic averages, minimum maximum 
Table 1. Distribution of surveyed patients by different variables

\begin{tabular}{lcc} 
Gender (Total=381) & F & \% \\
\hline Female & 228 & 59.8 \\
Male & 153 & 40.2 \\
\hline Age & Average & Min.-Max. \\
\hline & $46.12 \pm 18.92$ & $17-88$ \\
\hline ED diagnosis (Total=381) & F & $\%$ \\
\hline Central vertigo & 31 & 8.1 \\
Peripheral vertigo & 175 & 45.9 \\
Cardiac and blood & & 11.2 \\
pressure induced vertigo & 43 & 4.7 \\
Internal & 18 & 1.5 \\
Psychogenic & 6 & 28.3 \\
Other causes & 108 & \\
\hline
\end{tabular}

values and Standard deviation were utilized in summarizing continuous variables. Parametric tests were used to compare continuous variables according to categorical variables, and homogeneity counts of normality and variances were tested beforehand. Multiple regression analyses were performed to determine the relative importance of $\mathrm{CT}, \mathrm{MRI}$, and blood screening factors in the bills of patients who were admitted to emergency departments for vertigo. The chi-square analysis was performed to determine whether the patients had central pathology, based on whether or not they were scanned with MRI. In addition, the presence of central pathologies of patients based on whether a CT was performed was also assessed with the chi-aquare test.

\section{Results}

There were a total of 381 patients assessed as part of the study, 228 (\%59.8) of which were female, and 153 (\%40.2) male. By age, the average age of patients was determined to be 46,12 $( \pm 18,92)$, age range to be $17-88$; with a minimum of 17 years and a maximum of 88 years of age. Patients were grouped into six according to their ED diagnoses, those being the vertigo types: central, peripheral, cardiac or blood pressure-induced, internally induced, psychogenic and vertigo related to other causes (Table 1).
Table 2. Distribution of patients scanned with ct or mri

according to test results

\begin{tabular}{lcc} 
& F & $\%$ \\
\hline CT (Total=381) & & \\
Normal Findings & 47 & 12.3 \\
Chronic atrophic changes & 18 & 4.7 \\
Acute ischemia & 2 & 0.5 \\
Mass & 2 & 0.5 \\
Atrophic changes + acute ischemia & 2 & 0.5 \\
Other & 1 & 0.3 \\
Non-scanned & 309 & 0.81 \\
MRI (Total=381) & & \\
Normal findings & 24 & 6.3 \\
Acute diffuse restriction & 5 & 1.3 \\
Chronic ischemic findings & 2 & 0.5 \\
Mass & 3 & 0.8 \\
Other & 1 & 0.3 \\
Non-scanned & 346 & 90.8 \\
\hline
\end{tabular}

It was observed that CTs were performed on 72 (18.8\%) of central imaging patients and MRIs were performed on 35 (9.1\%). While most patients on which CTs were performed gave normal findings, it was seen that pathologically and most commonly, atrophic changes were observed. The most common pathology for patients who have been scanned with MRI was acute ischemic changes. All results were assessed to see that the CT was the most commonly preferred imaging method in diagnosis (Table 2).

The average of ED invoice costs and hospitalization periods of patients were assessed. According to this, the average ED invoice cost of patients was TL $75(\$ 39,4)$, and the Standard deviation values TL $66(\$ 34,7)$. The minimum value of invoice costs was determined as TL $11(\$ 5,7)$, while the maximum was TL $430(\$ 226,3)$.

The parameters that affect the ED invoice costs were assessed with the linear regression analysis (Table 3). According to the results, it was observed that the MRI, CT, CBC, Biochemistry Routine and Additional Tests were statistically meaningful parameters in predicting the Emergency Invoice Cost. The predictor variable with the biggest explanatory power according

Table 3. Simple linear regression analysis results

\begin{tabular}{|c|c|c|c|c|c|}
\hline Predictor variables & $\boldsymbol{\beta}$ & Standard error & Standardized $\beta$ & $\mathbf{t}$ & $\mathbf{p}$ \\
\hline MRI & 11.15 & 3.45 & 0.12 & 3.24 & 0.001 \\
\hline СТ 32.51 & 2.48 & 0.49 & 13.11 & 0.001 & \\
\hline $\mathrm{CBC}$ & 3.95 & 1.07 & 0.14 & 3.70 & 0.001 \\
\hline Biochemistry Routine & 3.91 & 1.83 & 0.09 & 2.14 & 0.033 \\
\hline Additional Tests & 29.14 & 3.91 & 0.30 & 7.45 & 0.001 \\
\hline $\mathrm{N}=364, \mathrm{R}^{2}=.56, \mathrm{p}=.001 ;$ Constant (32.62). & & & & & \\
\hline
\end{tabular}

The regression equation that can be used in estimating the invoice cost is as follows: $\hat{Y}=32.62+11.15^{*} \mathrm{MRI}+32.51{ }^{*} \mathrm{CT}+3.95 * \mathrm{CBC}+3.91 * \mathrm{BC}$ Routine+29.14*Additional Tests. 
Tablo 4. Neuroimaging costs according to diagnosis groups

\begin{tabular}{|c|c|c|c|c|}
\hline Result diagnoses & $\mathbf{C T}(\mathbf{f})$ & CT cost (TL) & MRI(f) & MRI cost (TL) \\
\hline Peripheral vertigo (Total=175) & $32(\% 18.2)$ & $1.936(\$ 1018.9)$ & $14(\% 8)$ & $1.001(\$ 526.8)$ \\
\hline induced vertigo (Total=43) & $9(\% 20.9)$ & $544.5(\$ 286.5)$ & $5(\% 11.6)$ & $357.5(\$ 188.1)$ \\
\hline Vertigo induced by internal causes (Total=18) & $2(\% 11.1)$ & $121(\$ 63.6)$ & $1(\% 5.5)$ & $71.5(\$ 37.6)$ \\
\hline
\end{tabular}

Tablo 5. Annual total and per patient costs according to diagnosis groups

\section{Result diagnoses}

Central vertigo $($ Total $=31)$

Peripheral vertigo (Total $=175$ )

Cardiac and blood-pressure

induced vertigo (Total $=43$ )

Vertigo induced by internal causes (Total $=18$ )

Psychogenic (Total=6)

Other (Total=108)
Total annual cost (TL)

$3.570(\$ 1.878 .9)$

$11.241(\$ 5.916 .3)$

$4.204(\$ 2.212 .6)$

$1.676(\$ 882.1)$

$476(\$ 250.5)$

$7.456(\$ 3.924 .2)$
Cost per patient (TL)

$115(\$ 60.5)$

$64(\$ 33.6)$

$97(\$ 51)$

93 (\$48.9)

79 (\$41.5)

$69(\$ 36.3)$ to the Standardized Beta values was the CT. The predictor variables altogether explained $56 \%$ of the invoice cost. Table 3 provides the Simple Linear Regression Analysis results.

The neuroimaging ratios and cost values according to result diagnoses have been given below (Table 4). According to this, it was determined that neuroimaging methods are used most on the patient group which is thought to have central vertigo. Despite the fact that the peripheral vertigo group has the highest number of patients, it was seen that the groups on which neuroimaging was used the least were the internally induced and peripheral vertigo groups. It was observed that the $\mathrm{CT}$ costs were higher than MRI costs for all patient groups. The group of which the neuroimaging cost is highest was seen to be the peripheral vertigo group.

The annual total cost was assessed according to result diagnoses, according to which costs per patient were calculated (Table 5). According to this, although the patient group with the highest total cost is the peripheral vertigo group, the one with the lowest cost per patient was also the peripheral vertigo group. It was determined that the group in which costs per patient were the highest was the patient group which was presumed to have central vertigo.

The total annual healthcare service cost of our department was TL 2.364.216 (\$1.244.324) The annual cost of patients complaining from vertigo was TL $28.623(\$ 15.064,7)$. TL 4.356 $(\$ 2.292,6)$ was spent on CT, while TL $2.502(\$ 1.316,8)$ was spent on MRIs. Accordingly, it was seen that the vertigo patients take up $1.2 \%$ of the total annual cost of our department. Neuroimaging costs, on the other hand, constituted $0.1 \%$ of the total annual cost.

\section{Discussion}

Vertigo is a complaint that affects $20-30 \%$ of the general population and is commonly seen in the EDs. ${ }^{[8]}$ Approximately $20 \%$ of elder patients (over 60 ) have been reported to experience serious vertigo attacks at a level that affects their daily activities. ${ }^{[9]}$ Vertigo affects life quality of patients negatively. Particularly repetitive vertigo attacks have serious social and economic effects, and these cause significant restrictions. ${ }^{[10]}$ Due to the fact that aetiology can only be determined with medical records and physical examination, it is important to know the approach to the patient who was admitted to emergency department for vertigo in terms of avoiding unnecessary tests, improving life quality with correct diagnosis and treatment, preventing labour loss, and for patients with a serious neurological disease, avoiding time loss. ${ }^{[1]]}$

Physicians, for central and peripheral vertigo to be distinguished, take advantage of the high sensitivity of and easy access to the radiological imaging methods. The frequent use of imaging methods for patients who apply to the hospital with complaints of vertigo also increases the annual invoice costs. Another reason for this increase is different factors playing a role in the aetiology of balance disorders, and the lack of a standard test to be used for diagnosis.

The vertigo complaint can be observed as a symptom of many diseases. A study conducted by Kroenke et al. has determined peripheral vertigo to be the most common reason for vertigo. This was followed by other reasons, psychiatric reasons, unknown reasons and central reasons. ${ }^{[3]} \mathrm{A}$ prospective study on 100 ambulant patients followed due to persistent vertigo has reported 54 patients to have vestibular disorders, 16 patients 
to have psychiatric disorders, and 10 patients central causes. ${ }^{[11]}$ Correlating with this information, in our study, peripheral vertigo was seen most commonly among patients and the highest number of patients were in this group. Other causes include cardiac and blood pressure induced vertigo followed by central causes. Central vertigo cases are the group of patients with the highest mortality in vertigo. In our study, ischemic stroke was the most frequently detected situations in central vertigo cases. CT is the most preferred imaging method to detect posterior fossa haemorrhages or large masses causing vertigo among central causes. ${ }^{[12]}$ The reasons for $\mathrm{CT}$ to be the first preference are; easy access, speed and CT being cheaper in comparison with MRls. Although frequently preferred, CT is of low value in the diagnosis of vertigo. ${ }^{[13]} \mathrm{MRI}$ is more advantageous in acute stroke assessment. Particularly diffusion oriented images provide convenience in comparison to $\mathrm{CT}$ in acute ischemic damage change assessment. ${ }^{[14-17]}$ However, MRI cannot be found in many EDs and is quite expensive. ${ }^{[18-22]}$ MRI sensitivity is lower than CT in internal brain haemorrhage cases where 6 hours have passed since the start.

In a retrospective study carried out in the USA in 2008, the number of patients admitted to EDs has been reported to have increased by $37 \%$ between 1995 and 2004. Again, it was seen that within the same time period, the number of CT and MRI scans requested for these patients had increased significantly, by $169 \%$. In a study conducted by Newman-Toker et al., it was observed that compared to the control group, patients who were admitted to emergency departments with complaints of vertigo have been asked tests and imagings at a significantly higher rate..$^{[18]}$

According to Gardner et al., the rate of CT and MRI use had increased more than all other tests in the evaluation of vertigo, but there was no change in the rate of determination of central nervous system pathologies. In the same study, the fact that there are no validated methods to distinguish the causes for vertigo between stroke and non-stroke cases was held responsible for the increasing imaging costs. ${ }^{[23]}$

The evaluation and management of patients who are admitted to ED with complaints of vertigo is quite expensive. It is estimated that the national cost of patients who have applied to EDs in the USA with complaints of vertigo have reached important values, and that these patients constitute $4 \%$ of the annual total emergency department costs by exceeding $\$ 4$ million. As far as we know, there are no studies conducted in Turkey that analyses the costs of this subject. Besides that, the studies on cost analyses in the literature are insufficient. According to a study carried out by Tehrani et al., the estimated number of patients who were admitted to the EDs for vertigo in 2011 in the USA is 3.9 million. ${ }^{[24]}$ The total cost estimate is $70 \%$ higher than the previous national cost estimate ( $\$ 1.1$ billion/1992, $\$ 2.32$ billion/2011, 3 equivalent national estimates). On average, the cost per admission is $\$ 1004$, with an overall cost of $\$ 3.9$ billion, in 2011 related to emergency department admissions for vertigo. The ratios of vertigo admissions, cost for each admission, annual national cost values are as follows;
$25.7 \%$, \$768, \$757 million for otologic/vestibular diseases; $16.5 \%$, \$1489, \$ 941 million for cardiovascular diseases, 3.1\%, $\$ 1059, \$ 127$ million for cerebrovascular diseases. Although the most common diagnoses are otologic and vestibular causes, it is estimated that cardiovascular diseases are associated with the total high cost of patients describing vertigo. The increase in costs has been argued to be associated with the increase in ED admissions over time (2.0 million admissions in 1995, 3.9 million admissions in 2011) and an increase in diagnostic imaging methods (from 10\% in 1995 to $40 \%$ in 2011). It has been shown in the study that the cost estimate may be in a wide range because the diagnostic tests were used disproportionately for patients with vertigo. In our study, similar to Tehrani et al.'s study, the group with the greatest number of patients and the highest total cost was found to be the group with peripheral causes. Unlike the above given study, central vertigo, in the cost-per-patient ratio, is seen to be more costly. In our study, the effect of the neuroimaging methods on the cost calculation was assessed, and thus clearer results were revealed. In our study, it was found that the costs (especially the cost of (T) were determined to be high due to the use of the neuroimaging methods in the central vertigo group. One study reported that $12 \%$ of the total costs of ED visits were due to neuroimaging methods. Accordingly, the cost of CT imaging was estimated at $\$ 360$ million, and the cost of MRI imaging was estimated at 110 million. Our study has found that the annual cost of vertigo patients constitutes $1.2 \%$ of the annual cost of our department, and the neuroimaging scans done on these patients constitute $0.1 \%$ of the total annual cost. The ratio was found to be lower than the study of Tehrani et al. ${ }^{[24]}$

\section{Conclusion}

The underlying pathologies in ED patients with vertigo vary in a wide spectrum. It has been seen that the cost of patients with vertigo has increased gradually due to the year-over-year increase in the number of emergency patients with vertigo and the unwillingness of physicians to bypass central causes. The fact that our study has come up with a lower cost compared to the literature is a positive finding for our ed, but it is also true that this is a problem in the context of all EDs. It may be possible to take under control unnecessary costs with good and accurate patient management in EDs. In our opinion, the lack of algorithms to standardize the selection of neuroimaging methods and to enable us to reach the diagnosis in the literature has an important share in this increase. In this patient group, it may be possible to reduce hospital costs by developing algorithms that enable us to reach diagnosis and provide access to diagnosis and start with medical records and physical examination findings.

Conflict of interest: There are no relevant conflicts of interest to disclose.

Funding: There is no funding sources and financial relationship for this study. 


\section{References}

1. Navi B.B., Kamel H., Shah M.P., Grossman A.W. Rate and predictors of serious neurological causes of vertigo in the emergency department. Mayo Clin Proc, 2012. 87(11): p. 1080-8.

2. Neuhauser HK. The epidemiology of dizziness and vertigo. Handb Clin Neurol. 2016;137:67-82. Review.

3. Kroenke K., Hoffman R.M., and Einstadter D. How common are various causes of vertigo? A critical review. South Med J, 2000; 93(2), 160-7.

4. Ozakin E., Coskun F., Sarac S. Value of magnetic resonance imaging and audiology in the emergency department in differential diagnosis of peripheral and central vertigo. Turkiye Klinikleri J of Med Sci, 2012; 32(1): 1-6.

5. Post R.E. and Dickerson L.M. Vertigo: A diagnostic approach. Am Fam Physician, 2010; 82(4): 361-368.

6. Collie M.J.H. and Ramsey A.R. Differentiating Benign Paroxysmal Positional Vertigo from Other Causes of Vertigo. JNP, 2014; 10(6): 393-400.

7. Kim A.S., Fullerton H.J. and Johnston S.C. Risk of vascular events in emergency department patients discharged home with diagnosis of vertigo or vertigo. Ann Em Med, 2011; 57(1): 34-41.

8. Neuhauser H.K., Von Brevern M., Radtke A., Lezius F. Epidemiology of vestibular vertigo: $A$ neurotologic survey of the general population. Neurology, 2005; 65(6): 898-904.

9. Karatas M. Central vertigo and vertigo: epidemiology, differential diagnosis, and common causes. The Neurologist, 2008; 14(6): 355-364.

10. Yardley L., Owen N., Nazareth I., Luxon L., Prevalence and presentation of vertigo in a general practice community sample of working age people. Br J Gen Prac, 1998; 48(429): 1131-1135.

11. Kroenke K., Lucas C.A., Rosenberg M.L., Causes of persistent vertigo: a prospective study of 100 patients in ambulatory care. Ann of Int Med, 1992; 117(11): 898-904.

12. Kim A.S., Sidney S., Klingman J.G., Johnston S.C., Practice variation in neuroimaging to evaluate vertigo in the ED. The Am J Emerg
Med, 2012; 30(5): 665-672.

13. Wasay M., Dubey N., and Bakshi R., Vertigo and yield of emergency head CT scan: is it cost effective? EMJ, 2005; 22(4): 312-314.

14. Fiebach J., Schellinger P.D., Jansen O., Meyer M., CT and diffusionweighted MR imaging in randomized order Diffusion-weighted imaging results in higher accuracy and lower interrater variability in the diagnosis of hyperacute ischemic stroke. Stroke, 2002; 33(9): 2206-2210.

15. Bryan R.N., Levy L.M., Whitlow W.D., Diagnosis of acute cerebral infarction: comparison of CT and MR imaging. Am J Neurorad, $1991 ; 12(4), 611-620$.

16. Mohr J.P., Biller J., Hilal S.K., Yuh W.T.C., Tatemichi T.K., Magnetic resonance versus computed tomographic imaging in acute stroke. Stroke, 1995; 26(5):807-812.

17. Warach S., Gaa J., Siewert B., Wielopolski P., Acute human stroke studied by whole brain echo planar diffusion-weighted magnetic resonance imaging. Anns of Neurology, 1995; 37(2): 231-241.

18. Newman-Toker D.E., Hsieh Y.H., Camargo C.A., Spectrum of vertigo visits to US emergency departments: cross-sectional analysis from a nationally representative sample. In Mayo Clinic Proceedings. 2008. Elsevier.

19. Edlow J.A., Newman-Toker D.E. and Savitz S.I., Diagnosis and initial management of cerebellar infarction. The Lancet. Neurology, 2008; 7(10): 951-964.

20. Kerber K.A., Brown D.L., Lisabeth L.D., Smith M.A., Stroke among patients with vertigo and imbalance in the emergency department: a population-based study. Stroke, 2006; 37(10),2484-7.

21. Seemungal B.M. and Bronstein A.M., A practical approach to acute vertigo. Practical neurology, 2008; 8(4), 211-221.

22. Labuguen R.H., Initial evaluation of vertigo. Am Fam Physician, 2006; 73(2):244-251.

23. Gardner R.L., Sarkar U., Maselli J.H., Factors associated with longer ED lengths of stay. The Am J Emerg Med, 2007; 25(6):643-650.

24. Saber Tehrani A.S., Coughlan D., Rising Annual Costs of Dizziness Presentations to US Emergency Departments. Acad Emerg Med. 2013 Jul;20(7):689-96. 